\title{
No Difference in Antler Asymmetries Between Two Captive Maral Deer Populations
}

\author{
No Existen Diferencias de Asimetría de las Astas entre \\ Dos Poblaciones de Ciervo Rojo en Cautiverio
}

Korzhikenova, N."; Sambetbaev, A."; Iglikov, O.** \& Parés-Casanova, P. M.***

KORZHIKENOVA, N.; SAMBETBAEV, A.; IGLIKOV, O. \& PARÉS-CASANOVA, P. M. No difference in antler asymmetries between two captive maral deer populations. Int. J. Morphol., 32(1):12-15, 2014.

SUMMARY: The objective of this study was to investigate asymmetry in antlers of Caspian Red Deer or maral (Cervus elaphus sibiricus) from two different genetic origins and maintained under similar conditions. Eighteen male Caspian Red Deer aged 24 months were studied. Nine animals belonged to the local Kazakh population and nine were directly imported Russian deer. The following data were obtained for right and left antlers: wet weight, stem length and circle and 1st, 2nd and 3rd shoot lengths. To obtain the values of antler asymmetries we used the absolute differences between the value of each trait on left and right sides. According to values of asymmetries obtained, the two populations neither showed differences from each other nor exhibited consistent directional trends in mean measures. Therefore, it could be concluded that Russian marals have adapted well to environmental conditions, presenting no different levels of environmental stress in relation to local Kazakh ones.

KEY WORDS: Horn; Antler; Maral; Symmetries.

\section{INTRODUCTION}

Fluctuating asymmetry (FA) is random deviation from perfect symmetry in traits that are normally bilaterally symmetrical. Because these traits arise from the same genome, their optimal condition is assumed to be perfect symmetry (Polak \& Trivers, 1994). Therefore, a departure from symmetry indicates disruption of normal development, most likely due to genetic or environmental stresses (Parsons, 1992). Environmental stressors increase asymmetry in a variety of organisms (Møller \& Swaddle, 1997). So, as FA can reliably reflect the stress experienced during development, it has been suggested that it could be related to (or predict) individual fitness (Møller, 1990). If so, symmetry of bilateral sexual traits (both weapons and ornaments) may play an important role in sexual selection because symmetric individuals might have an advantage over asymmetric competitors during mate choice or intrasexual competition (Møller, 1990).

Ornamental traits and secondary sexual characteristics are important factors influencing mate choice and intrasexual competition in many species (Andersson,
1982; Mateos \& Carranza, 1997; Møller, 1988; Pärt \& Qvarnström, 1997). Also, several studies have documented that females prefer more symmetrical males (López et al., 2002; Schlüter et al., 1998; Sheridan \& Pomiankowski, 1997). Therefore, it is hypothesized that the symmetry of these ornamental traits may play an important role in mate choice and, hence, have important implications for sexual selection.

This proposed relationship between fluctuating asymmetry and quality has been studied for a variety of different traits. However, not every trait shows an increase in fluctuating asymmetry with increased stress; different traits appear to be under different levels of stabilizing selection. Many morphological traits, especially those used in functions related to survival, are highly canalized and therefore are less susceptible to developmental disturbance (Polak, 1993). Other traits seem to be much more susceptible to stress. These include characters that are under directional selection, such as ornamental traits (Møller \& Pomiankowski, 1993).

* Dept. of Production technology of animal husbandry and fish culture products, Kazakh National Agrarian University, Almaty, Kazakhstan.

** Dept. of Biology, Semey State University named after Shakarim, Semey, Kazakhstan.

*** Dept. of Animal Production, University of Lleida, Catalunya, Spain. 
The objective of this study was to investigate asymmetry in antlers of Caspian Red Deer or maral (Cervus elaphus sibiricus) from two different genetic origins, maintained under similar conditions. Specifically, we tested for the hypothesized negative relationship between levels of FA and environmental stress. The maral is one of the easternmost subspecies of Red deer, native to areas in Kazakhstan, China, Mongolia and Russia. They are large and strong animals: adult deer can be up to $150 \mathrm{~cm}$ high and up to $260-330 \mathrm{~kg}$ in weight for males and $150-250 \mathrm{~kg}$ for females. Stem length and weight of antlers depend on $t$ age and heredity. The amplitude of oscillation is very large. For example, at 6 years of age (they have the greatest productivity at 6-12 years of age) the average weight of antlers is $9.9 \mathrm{~kg}$ $(2.0-11.9 \mathrm{~kg})$ and the length of the stem is $64.8 \mathrm{~cm}(45-83$ $\mathrm{cm}$ ) (Lunitsyn, 2004). Red deer are highly appreciated in livestock farming for the supposed healing properties of the young individuals' antlers, so called "Siberian deer antlers". These antlers are used to prepare a stimulating medicinal agent, called pantocrine. "Siberian deer antlers" are used to treat blood, cardiovascular, and cranial diseases, and as a preventive against weakening of the immune system and nervous system problems. The antlers are also used as a tonic, rejuvenating drug.

\section{MATERIAL AND METHOD}

Sampling. Eighteen male marals aged 24 months were studied. Nine animals belonged to the local Kazakh population and nine to Russian ones. Both were managed under similar conditions.

Local marals were obtained from the peasant farm "Bagration" (East Kazakhstan region, Ulan area, village of Privolnoye, $\left.50^{\circ} 06^{\prime} \mathrm{N}, 81^{\circ} 32^{\prime} \mathrm{E}\right)$. This farm has the status of a pedigree factory and breeding farm, breeding Kazakh white cattle and Simmental cattle. Maral and horse breeding are additional branches. The farm is located in a dry-steppe zone; the climate is sharp continental, with large daily and annual temperature fluctuations, spanning from $-52.5^{\circ} \mathrm{C}$ in winter to $+40^{\circ} \mathrm{C}$ in summer. The average temperature in January is $-16^{\circ} \mathrm{C}$ and in July $+20.5^{\circ} \mathrm{C}$. The average annual precipitation is between 180 and $230 \mathrm{~mm}$. Average thickness of the snow cover is $30-40 \mathrm{~cm}$ but it can range between 5 and $80 \mathrm{~cm}$ in individual winters. The soils are dark chestnut and solonetsic. Vegetation: feather grass, fescue, rump, timothy grass, origan, clover, vetch and wormwood.

Russian marals were from the agricultural production cooperative breeding factory "Tenginsky" (Altai Republic, Ongudai area, village of Tenga, $50^{\circ} 50^{\prime} 34^{\prime \prime} \mathrm{N}, 85^{\circ} 39^{\prime} 22^{\prime \prime}$
E). This farm also has the status of a pedigree factory, breeding the Altai-Sayan breed of marals. The farm is located in a mountain-steppe zone; the climate is sharp continental with large daily and annual fluctuations in temperature, extending from $-49^{\circ} \mathrm{C}$ in winter to $+37.5^{\circ} \mathrm{C}$ in summer. The average temperature in January is $-16^{\circ} \mathrm{C}$, in July $+13^{\circ} \mathrm{C}$. The average annual precipitation is around $\mathrm{mm}$. Average thickness of the snow cover is $30-45 \mathrm{~cm}$, varying from 6 $\mathrm{cm}$ in valleys to $1.5 \mathrm{~m}$ in mountains. The soils are chernozems, gray forest, sod-podzolic, steppe, mountainmeadow and mountain tundra. Vegetation: larch, karagan, barberry, honeysuckle, kurilian tea, maral root, cowberry, pion herb and chabrets.

Measurements. The following data were obtained for right and left antlers: wet weight, stem length and circle and 1st, 2nd and 3rd shoot lengths. All variables were considered to describe the trait "conformation". Each measurement was taken once, always by the first author (KN). Animals were measured in vivo using a subjection catch, so no ethical permission was needed.

Analysis of FA. To obtain a measure of FA it was applied to the absolute difference between the values of a trait on the left and right sides. Higher values in these differences would indicate less symmetric antlers. As each trait can provide an independent estimate of the underlying developmental instability of an individual (Palmer \& Strobeck, 1986), the five studied measurements for each antler were used independently: stem length and circle, 1st, 2nd and 3rd shoot length per male. Because asymmetry measures were not normally distributed, they were log transformed.

Data analyses. Shapiro-Wilks' tests for normality of the distributions of studied parameters for each population were conducted. Equality of the means of the two groups was evaluated by a Hotelling's T-squared test. Finally, a correlation table between measurements and fresh weight of both antlers was done in order to see if there was any relationship between asymmetries and weight, the latter being interpreted as an indicator of quality. All analyses were performed using the PAST program (Hammer et al., 2001).

\section{RESULTS}

The main statistics for both populations appear in Table I. Antler weight was not correlated $(\mathrm{p}<0.05)$ with any of the measurements. Hotelling's test showed no difference between the two populations according to the antlers' conformation $(\mathrm{F}=1.752, \mathrm{p}<0.05)$. Classification was correct in $88.89 \%$ of cases. The distributions of all studied parameters - mean 
Table I. Main statistics for each population ( $\mathrm{n}=9$ for each). Measurements are in $\mathrm{cm}$ except for weight, which is in $\mathrm{kg}$.

\begin{tabular}{|c|c|c|c|c|c|}
\hline \multirow{2}{*}{$\begin{array}{l}\text { Population } \\
\text { Variable }\end{array}$} & \multirow[b]{2}{*}{ Side } & \multicolumn{2}{|c|}{ A } & \multicolumn{2}{|c|}{ B } \\
\hline & & Range & Mean士SD & Range & Mean \pm SD \\
\hline Wet weight & Right & $1-1.8$ & $1.4 \pm 0.273$ & $1-1.7$ & $1.3 \pm 0.281$ \\
\hline Wet weight & Left & $1.1-1.7$ & $1.5 \pm 0.212$ & $1.1-1.8$ & $1.3 \pm 0.264$ \\
\hline Stem length & Right & $47-65$ & $53.8 \pm 5.840$ & $37-53$ & $45.6 \pm 5.522$ \\
\hline Stem length & Left & $48-68$ & $55.6 \pm 7.141$ & $39-52$ & $47.3 \pm 4.657$ \\
\hline Stem circle & Right & $13-17$ & $14.5 \pm 1.333$ & $13-17$ & $14.4 \pm 1.130$ \\
\hline Stem circle & Left & $13-17$ & $14.8 \pm 1.691$ & $13-17$ & $14.6 \pm 1.302$ \\
\hline $1^{\text {st }}$ shoot & Right & $17-32$ & $21.7 \pm 4.944$ & $13-22$ & $18.4 \pm 2.877$ \\
\hline $1^{\text {st }}$ shoot & Left & $14-35$ & $23.0 \pm 6.204$ & $16-23$ & $19.7 \pm 2.712$ \\
\hline $2^{\text {nd }}$ Shoot & Right & $20-31$ & $24.7 \pm 3.734$ & $12-27$ & $19.5 \pm 6.454$ \\
\hline $2^{\text {nd }}$ Shoot & Left & 20-33 & $26.0 \pm 4.555$ & $8-27$ & $20.5 \pm 8.736$ \\
\hline $3^{\text {rd }} s_{\text {hoot }}$ & Right & $18-22$ & $20.7 \pm 1.164$ & $14-22$ & $16.8 \pm 2.356$ \\
\hline $3^{\text {rd }}$ Shoot & Left & $18-27$ & $21.7 \pm 2.764$ & $15-20$ & $18 \pm 1.732$ \\
\hline
\end{tabular}

values for each animal -did not depart from normality as indicated by Shapiro-Wilks' tests ( $\mathrm{p}<0.05$ ). According to logtransformed asymmetries, the two populations did not show differences either $(\mathrm{F}=0.394 \mathrm{p}<0.05)$ and exhibited no consistent directional trends in mean measures.

\section{DISCUSSION}

FA, random departure from perfect symmetry in bilateral traits, has been proposed as an indirect indicator of individual quality. But according to obtained data, Russian and local populations have no differences in antler conformation and neither do they present different asymmetries. So it could be concluded that Russian marals have adapted well to environmental conditions, presenting no different quality levels of environmental stress in relation to local ones. Moreover, if symmetry and masculinity indicate the quality of individuals, high quality individuals should develop large antlers that have little asymmetry. As, according to our results, size was unrelated to symmetry, it could be expected that the cost of larger ornamentation would create developmental stress for their owners, heavier individuals not being the only ones capable of bearing the handicap of growing large traits or symmetries. If sexual characters, like antlers, are costly to produce (Ditchkoff \& deFreese, 2010) the relative cost to produce equal-sized traits would be the same for lighter weight individuals. This might not be the case in wild animals, but can be explained in this research by the fact that the studied animals are bred in an artificial environment, so those costs may be perfectly covered.

Measured sexual dimorphism may not capture all aspects of this trait to which deer are visually sensitive. So an objection to our study is that we have examined FA of antlers only through simple measures. But antlers are complex, 3-dimensional traits making it difficult to quantify all forms of visual asymmetry using traditional, linear measurements (Ditchkoff $\&$ deFreese). It is this visual asymmetry that would be assessed by potential mates and rivals. Therefore, 3-dimensional comparisons would be more useful to assess asymmetries.

ACKNOWLEDGMENTS. We wish to thank all the workers at the deer-farm "Bagration", who have always been ready to cooperate and help in any necessary way on occasions of field research.

KORZHIKENOVA, N.; SAMBETBAEV, A.; IGLIKOV, O. \& PARÉS-CASANOVA, P. M. No existen diferencias de asimetría de las astas entre dos poblaciones de ciervo rojo en cautiverio. Int. J. Morphol., 32(1):12-15, 2014.

RESUMEN: El objetivo de este estudio fue investigar la asimetría en las astas del Ciervo Rojo del Mar Caspio o Maral (Cervus elaphus sibiricus) en dos rebaños de origen genético diferente y mantenidos bajo condiciones similares. Se estudiaron 18 ciervos rojos del mar Caspio (machos) de 24 meses de edad. Nueve de los 18 animales pertenecían a la población nativa de Kazajistán y nueve fueron importados directamente desde Rusia. Se obtuvieron los siguientes datos para las astas derecha e izquierda: peso húmedo, longitud del tallo, circunferencia y primera, segunda y tercera longitud de los cuernos. Para obtener los valores de asimetrías de las astas se registraron las diferencias absolutas entre el valor de cada rasgo, izquierdo y derecho. De acuerdo a los valores obtenidos de las asimetrías, no se registraron diferencias entre ambas poblaciones, tampoco se observaron tendencias direccionales consistentes en el promedio de medidas. El ciervo rojo ruso se ha adaptado bien a las condiciones ambientales y no presentó niveles de estrés ambiental diferentes en relación con los animales nativos de Kazajistán.

PALABRAS CLAVE: Cuerno; Asta; Ciervo; Simetría. 


\section{REFERENCES}

Andersson, M. Female choice selects for extreme tail length in a widowbird. Nature, 299:818-20, 1982.

Ditchkoff, S. S. \& deFreese, R. Assessing fluctuating asymmetry of white-tailed deer antlers in a three-dimensional context. J. Mammal., 91(1):27-37, 2010.

Hammer, Ø.; Harper, D. A. T. \& Ryan, P. D. PAST: Paleontological Statistics Software Package for Education and Data Analysis. Palaeontología Electrónica 4(1), 2001. Available in: http://palaeo-electronica.org/ 2001_1/past/past.pdf

López, P.; Muñoz, A. \& Martín, J. Symmetry, male dominance and female mate preferences in the Iberian rock lizard, Lacerta monticola. Behav. Ecol. Sociobiol., 52(4):342-7, 2002.

Lunitsyn, V. G. Antler deer breeding of Russia. Barnaul, Russian Academy of Agricultural Sciences, Siberian branch of the Russian Research Institute of antler deer breeding, 2004. pp.151-9.

Mateos, C. \& Carranza, J. Signals in intra-sexual competition between ring-necked pheasant males. Anim. Behav., 53(3):471-85, 1997.

Møller, A. P. Female choice selects for male sexual tail ornaments in the monogamous swallow. Nature, 332:640-2, 1988.

Møller, A. P. Fluctuating asymmetry in male sexual ornaments may reliably reveal male quality. Anim. Behav., 40:1185-7, 1990.

Møller, A. P. \& Pomiankowski, A. Fluctuating asymmetry and sexual selection. Genetica, 89:267-79, 1993.

Møller, A. P. \& Swaddle, J. P. Asymmetry, Developmental Stability, and Evolution. In: Oxford series in Ecology and Evolution. Oxford, Oxford University Press, 1997.

Palmer, A. R. \& Strobeck, C. Fluctuating asymmetry: measurement, analysis, patterns. Annu. Rev. Ecol. Syst., 17:391-421, 1986.

Parsons, P. A. Fluctuating asymmetry: a biological monitor of environmental and genomic stress. Heredity, 68(Pt. 4):361-4, 1992.
Pärt, T. \& Qvarnström, A. Badge size in collared flycatchers predicts outcome of male competition over territories. Anim. Behav., 54(4):893-9, 1997.

Polak, M. Parasites increase fluctuating asymmetry of male Drosophila nigrospiracula: implications for sexual selection. Genetica, 89:255-65, 1993.

Polak, M. \& Trivers, R. The science of symmetry in biology. Trends Ecol. Evol., 9(4):123-5, 1994.

Schlüter, A.; Parzefall, J. \& Schlupp, I. Female preference for symmetrical vertical bars in male sailfin mollies. Anim. Behav., 56(1):147-53, 1998.

Sheridan, L. \& Pomiankowski, A. Female choice for spot asymmetry in the Trinidad guppy. Anim. Behav., 54(6):1523-9, 1997.

\section{Correspondence to: Korzhikenova, N.}

Dep. of Production technology of animal husbandry and fish culture products.

Kazakh National Agrarian University

Almaty

KAZAKHASTAN

Email: nurgul86@mail.ru

Received: 15-04-2013

Accepted: 23-12-2013 